\title{
A LIQUIDITY RISK STRESS-TESTING FRAMEWORK WITH BASEL LIQUIDITY STANDARDS*
}

\section{Hana Hejlováa,b, Zlatuše Komárkováa,c, Marek Rusnák ${ }^{a}$}

\begin{abstract}
We present a macro stress-testing model for banks' market and funding liquidity risks with a survival period of one year. The model follows the main principles of the Basel standards LCR and NSFR. Besides, the model takes into account the impact of both bank-specific and market-wide scenarios and includes second- round effects of shocks due to banks' feedback reactions. The presented methodology is then applied to a sample of Czech banks. This allows us to monitor the sensitivity of their liquidity position to the combination of shocks under consideration.
\end{abstract}

Keywords: banking, financial stability, liquidity, stress testing

JEL Classification: G12, G19, G21

\section{Introduction and Literature}

Asset and liability maturity mismatch is one of the key features of banking business. Limiting that mismatch to a reasonable level, or at least covering it with enough liquid assets, is one of the main aims of European regulations. The Basel III standard introduced two requirements to strengthen bank liquidity management: a liquidity coverage ratio (LCR) and a net stable funding ratio (NSFR). ${ }^{1}$ Both are based on assumptions about

a Czech National Bank, Prague, Czech Republic

b Charles University, Institute of Economic Studies, Faculty of Social Sciences, Prague, Czech Republic

c University of Finance and Administration, Prague, Czech Republic

Email: hana.hejlova@cnb.cz, zlatuse.komarkova@cnb.cz, marek.rusnak@cnb.cz

* This research has been prepared under the project New Sources of Systemic Risk in the Financial Markets, supported by the Czech Science Foundation (No. 16-21506S, 2016-2018) and using institutional support for the long-term conceptual development of the research organization University of Finance and Administration.

1 The LCR represents a requirement to hold sufficient liquid assets to cover net liquidity outflows over a 30-day period. The NSFR is defined as the amount of available stable funding relative to the amount of required stable funding. This ratio should be equal to at least $100 \%$ on an on-going basis. 
liquidity inflow and outflow rates, asset quality and liquidity, and funding source stability over a given period (BCBS, 2013a, 2014). Those two requirements should be viewed as harmonised minimum standards that do not necessarily reflect all the national specificities of the banking sector. ${ }^{2}$ It should also be emphasized that the LCR (considered to be a short-term stress test) neither assumes any haircuts on high-quality domestic government bonds nor does it include any second-round effects. For this and other reasons, it is essential to have an additional methodology able to assess the magnitude of liquidity risk within the banking sector.

This article describes a liquidity stress-testing framework that is based on metrics similar to the two Basel liquidity regulatory standards: the LCR and the NSFR. ${ }^{3}$ Besides, the presented test includes endogenous reactions of banks (so-called adverse feedback loop) to the first round of initial shock, creating additional liquidity shocks in the second round. In this part of the methodology, we were inspired by van den End (2008), Aikman et al. (2009), Nier et al. (2008) and Geršl et al. (2016). They have all tried to quantify the relationship between the value of banks' liquidity reserves and market liquidity, which is impaired once the assets are liquidated on the market during periods of stress.

Macro stress tests are part of the prudential toolkit that supervisors in particular use to detect system-wide liquidity risk. However, for liquidity risk, the stress testing methods are currently not as advanced as those applied to credit risk. Most supervisory authorities perform routine liquidity stress test where scenario shocks, such as haircuts on assets and liability run-off assumptions are applied to balance sheet positions (Bank of Japan, Sveriges Riksbank or Bank of Italy, for example, as presented in their financial stability reports). Our presented stress-testing framework includes interactions between solvency and liquidity, where a scenario is constructed as a simulated shock to bank credit portfolios that spills over into market and funding liquidity risk. The concept of banking sector liquidity and its interaction with solvency has been analysed extensively in the literature, especially since the fall of Lehman Brothers. Researchers have examined the interaction between the deposit outflow rate and the probability of default (Wong and Hui, 2009) and profitability (Komárková et al., 2011; Geršl et al., 2016), among other things. Close interlinkages have also been found between various solvency indicators and the rating of a bank and its funding costs (BIS, 2015). A range of modelling approaches has been

2 See Article 98 of the CRD and also EBA (2014): Guidelines on common procedures and methodologies for SREP (12/2014).

3 A variation of this model is used by the Czech National Bank for its annual top-down liquidity stress-testing exercise (CNB, 2016a; Komárková et al., 2016). The model presented here shows some differences from the official CNB model; therefore, the results of the presented simulations differ from the results in official CNB publications. 
developed, evolving to macro stress tests with the aim of establishing macrofinancial linkages and integrated frameworks to model dynamic and systemic effects. They draw on theoretical work on modelling financial crises (e.g., Allen and Gale, 2000; Cifuentes et al., 2005). More complex integrated frameworks are still used rarely. One of the earliest integrated models is the model of the Central Bank of Austria, which integrates satellite models of credit and market risk with a network model to evaluate the probability of bank default (Boss et al., 2006). Another advanced model is the Bank of England's RAMSI model (Alessandri et al., 2009), which includes an interbank network model and an asset price function to simulate fire sales of assets and satellite models for credit risk. More advanced liquidity stress tests in integrated stress-testing frameworks combining credit, market and liquidity risk models are also used by other supervisory authorities (e.g., the Canadian and Norwegian central banks or the IMF (Čihák, 2007; Schmieder et al., 2012). In this way, the effect of a credit shock generated by a macro-financial scenario on a bank's liquidity or funding sources is tested (see, for example, Gauthier and Souissi, 2010). A decrease in liquidity inflows due to growth in non-performing loans or the credit spread in the case of bonds is considered most often. Some models also test the reverse linkage, where increased funding costs and/or losses on fire sales of assets affect the solvency of banks via their profit and loss accounts (Cetina, 2015; Puhr and Schmitz, 2014; Schmieder et al., 2012). Systemic feedback effects caused by banks' reactions (e.g., van den End, 2012), including interbank contagion (e.g., Bank of Korea, 2012; Gauthier and Souissi, 2010), are thus an integral part of advanced tests.

The correlation between credit risk and liquidity risk, however, is not easy to model. Credit risk builds up slowly in the system and has a gradual impact on banks' liquidity, whereas liquidity shocks occur suddenly and have a rapid impact on solvency. For these reasons, our model takes into account a one-year stress period with a gradual impact of a credit shock on banks' liquidity position. The impacts of the individual types of shocks will help better assess the sensitivity of the banking liquidity over a longer period.

As regards the determinants of liquidity of the Czech banking sector, Vodová (2011a) finds out that the liquidity of the sector increases with higher capital adequacy, higher interest rates on loans, higher share of non-performing loans and higher interest rates on interbank transactions. On the other hand, liquidity is negatively influenced by financial crises, higher inflation rates and GDP growth rates. In the analysis, the author uses unconsolidated and profit and loss data of the vast majority of the sector to explain four different liquidity ratios in a panel data regression using bank-specific as well as macroeconomic data for the period 2001-2009. Contrary to these results, using a Grangercausality test, Horváth et al. (2014) show that capital is found to negatively Granger-cause liquidity creation. To this end, they use balance sheet data for all Czech banks for the period 
2000-2010. A negative relationship between liquidity and capital adequacy is also found in other countries of the CEE region in Vodová (2013a), who performs a cross-country analysis for the Czech Republic, Hungary, Slovakia and Poland. In the study, the author attempts to explain the liquid asset ratio using panel data regression on unconsolidated bank balance sheet data for the period 2000-2011. Apart from this, the results point at differences between the drivers of the banks' liquidity in the region. Result for the individual countries are then specified in country-specific analyses in which the drivers of the bank liquidity are analysed using several different liquidity ratios (Vodová, 2013b for Hungary; Vodová, 2012 for Poland; Vodová, 2011b for Slovakia).

In terms of compliance with the LCR recommendation, EBA (2019) shows that the Czech Republic, Hungary, Poland and Slovenia are outstanding among the EU countries with regard to the fact that liquid assets in their banking sectors are predominantly composed of securities (excl. covered bonds). In terms of inflows, a relatively high share of cash inflows over total assets in Slovakia and Poland is from non-financial customers. In Hungary, on the other hand, most of these inflows are from financial customers. Apart from this, Hungary shows higher proportions of non-operational deposits. Also, the Czech Republic and Hungary are among the countries with the highest amount of liquid assets and outflows over total assets. Overall, the analysis is based on COREP data for a sample of 140 banks in the $28 \mathrm{EU}$ countries, Iceland and Norway. As of 30 June 2018, EU banks' average LCR was $146 \%$ according to the study. Even though the LCR in the Polish banking sector was found to be among the lowest, all the CEE countries including Poland comply with the LCR requirement of $100 \%$ comfortably. The LCR in the Czech, Hungarian and Slovak banking sectors was then found to be at the average of the EU countries or slightly above it.

This article is divided into two main parts. The first part describes the methodology and the second one presents illustrative examples of application of the methodology based on data for the Czech banking sector.

\section{The Concept of the Approach}

In our article, we build the liquidity stress test upon the approach presented mainly in Geršl et al. (2016) and in van den End (2008), and we develop it further. We follow a methodology that covers the interaction between balance-sheet liquidity (concerning the liquidity and maturity transformation function of a bank) and market liquidity (its ability to monetise its assets at a set price) and the banking sector's reactions. The model is a two- round one and we consider three successive steps. The banking sector is first hit by scenario-defined exogenous shocks on which banks react under certain conditions. Those reactions increase the reputational risk of each reacting bank and the systemic risk in the banking sector 
as a whole (endogenous shocks). Banks have a limited ability to increase their balancesheet totals over the entire test period. For example, they cannot raise additional funds by issuing securities, borrowing on the money market or from central banks, ${ }^{4}$ and funds are not deposited back in the bank once they have been withdrawn.

The main changes compared to the test presented by Geršl et al. (2016) and by van den End (2008) are as follows: (i) our liquidity test is linked to solvency macro-stress tests and scenarios, (ii) four three-month maturity bands are included, extending the stress period to one year, ${ }^{5}$ and (iii) metrics similar to the Basel LCR (calculation of the ratio) and the Basel NSFR (the maturity mismatch profile and the stress period) are included.

The approach focuses on testing whether a bank holds a sufficient buffer of liquid assets in relation to its maturity mismatch. To assess banks' resilience to liquidity risk we use a liquidity indicator defined as the ratio of the liquidity buffer to net expected liquidity outflows, i.e., the difference between liquidity outflows and inflows. The calculation of the liquidity indicator follows the LCR and the NSFR in some aspects. Like the LCR, the LI is used to test whether the liquidity buffer is sufficient to meet accumulated net outflows; nevertheless, it does so across four three-month maturity bands (the feature of the NSFR). Unlike the LCR requirement with its one-month stress period, the LI with its one-year period allows us to take into account the rate of accumulation of maturity mismatch in the bank's balance sheet. Like the LCR, for the calculation of the LI the amount of inflows, which can offset outflows, is capped. However, haircuts, inflow rates and outflow rates are set in the presented approach differently to values (factors) introduced by Basel III (BCBS, 2013a and 2014). The main reason is that the presented approach is designed for a one-year horizon and uses four maturity bands (four quarters, see note 6). In other words, we use four different values of haircuts, inflow rates and outflow rates entering equations below depending on the quarter being tested. Values of the haircuts and the inflow rates are empirically obtained from mutually consistent modelling simulations of the macro-financial scenario. ${ }^{6}$ Merely the outflow rates are based on the factors from the LCR. The factors are set as floors that are increased by an add-on. The amount of add-on depends on the resulting capital adequacy ratio after

4 The methodology assumes no government assistance or central bank reactions in order to assess the ability and scope of banks to survive without support. As central bank tools are an element of lender-of-last-resort policy, application of those tools is not considered in the tests.

5 Put simply, the test uses quarterly data and maturity bands of 0-3 months (Q1), 3-6 months (Q2), 6-9 months (Q3) and 9-12 months (Q4).

6 For the purposes of this article, we use for projections of relevant parameters CNB models macro-financial scenarios were created using the prediction model DSGE g3 (Andrle et al., 2009; Brázdik et al., 2011), satellite models for house prices (Hlaváček and Komárek, 2009), for credit growth, PD and LGD (Geršl et al., 2012), and for the yield curve (Kučera et al., 2019). 
applying the macro-stress test. Simply said, the greater the impact of macro-stress shock on the capital ratio, the higher the add-on applied.

The test can be summarised as follows. Exogenous shocks are applied to selected types of balance-sheet or off- balance-sheet items, outflows and inflows in each maturity band. In the second to fourth maturity bands, the items included in the liquidity buffer are additionally subjected to endogenous shocks caused by banks' reactions. The size of the reaction is determined by the difference between the liquidity outflow and inflow in each bank in the monitored bands. Two situations can arise: the bank has a sufficient liquidity buffer and reacts by using it to cover net outflows, or the bank reacts by deploying its liquidity buffer, which, however, does not cover its net expected outflows due to excessive maturity mismatch in a balance sheet dominated by unstable funding sources. The liquidity buffer is deemed sufficient if the bank can meet its accumulated net outflows (across the four maturity bands) over a one-year period. A sufficient LI thus takes a minimum value of one.

In the first step of the stress test, we simulate three different types of exogenous shock expressed in terms of a haircut on the asset value $(h)$, a haircut on the capped expected liquidity inflow $(p)$ and a run-off rate or draw- down rate expressing the rate of liquidity outflow $(r)$. The maximum haircut rate is $100 \%$. The liquidity indicator can then be expressed as:

$$
\begin{aligned}
& L I_{Q t}^{b}=\frac{L R_{Q t}^{b}}{N e t O u t_{Q t}^{b}}, \text { where } t=1,2,3,4, \\
& L R_{Q t}^{b}=\sum_{i} L A_{Q t i}^{b}\left(1-h_{Q t i}^{b}\right), \text { where } t=1,2,3,4,
\end{aligned}
$$

where, in the numerator (Equation 1), the liquid asset buffer $(L R)$ of each bank $(b)$ is defined as the sum of the market values of assets ( $L A)$ easily and immediately converted into cash being subject to a haircut $(h)$ applied according to the scenario (Equation 2). Among these assets $(i)$ we include cash, claims on the central bank excluding minimum reserves, unencumbered debt securities, stocks and collateral accepted. In the baseline, securities included in the liquidity asset buffer are not differentiated in terms of credit quality, which means that they are not capped according to their credit risk; instead, all unencumbered tradable debt securities are recognised. The different credit quality of securities is expressed using appropriate haircuts specified in the stress scenario. The net liquidity outflow (NetOUT) is in the denominator. The NetOUT is defined (Equation 3) as the total expected cash outflows minus total expected cash inflows in the specified stress scenario for the 90 subsequent calendar days ( $Q$ as the relevant maturity band, where $Q 1$ is the first maturity band of 0-3 months, $Q 2$ of 3-6 months, $Q 3$ of 6-9 months, $Q 4$ of 9-12 months). The NetOUT can be expressed by the following relation: 


$$
\operatorname{NetOUT} T_{Q t}^{b}=\sum_{k} O U T_{Q t k}^{b}-\operatorname{cap} \sum_{l} I N_{Q t 1}^{b}\left(1-p_{Q 1}^{b}\right), \text { where } t=1,2,3,4
$$

Among outflows $(O U T)$ we include liabilities due in the given band (e.g., retail deposits, wholesale funding and issued debt securities), credit line drawdowns and new loans. The run-off or draw-down rate of individual outflows $(k)$ is given by the parameter $(r)$. The total expected cash outflows are calculated by multiplying the outstanding balances of various outflows $(k)$ by the appropriate outflow rate $(r)$. Expected contractual inflows including interest payments $(I N)$ comprise contractual receivables $(l)$ due in the given band, for some of which an inflow of only a part thereof is assumed $(1-p)$. To prevent banks from relying solely on expected inflow to meet their liquidity needs, and also to ensure a minimum level of liquid asset holdings, the expected inflows are aggregately capped (cap) under the scenario. ${ }^{7}$ The total expected inflows are calculated by multiplying the outstanding balances of various $(l)$ by the appropriate inflow rates $(1-p)$ at which they are expected to flow in under the scenario up to an aggregate cap of the scenario-given percent of total expected cash outflows.

The haircuts $(h)$ reflect the fall in market prices of assets $(L A)$ and the lower proceeds that would come from selling/pledging them if they had to be monetised to cover a cash outflow. The haircuts are applied in the form of an interest rate shock to debt securities and as an equity shock. Two types of interest rate risk are taken into account. The first one is the general interest rate risk, which is defined as the risk of a change in the market price of an asset due to a change in the market interest rates used to value cash flows arising from ownership of the asset. The second one is the credit spread risk, which is defined as the risk of a change in the market price of an asset due to a change in the risk premium of the asset as perceived by the financial market. The impact of the materialisation of both interest rate risks on the value of debt securities is computed separately for the portfolio of debt securities issued by domestic/foreign government, credit institutions and other corporations, with a differentiation of the currency of issue. The haircut concerning general interest rate risk is calculated separately for each issue in a portfolio available for sale and depends on the projected paths of the government yield curves in the scenario and on the average residual maturity. It generally holds that larger general interest rate haircuts are applied in the case of higher growth in the yield curve or longer residual maturities. The haircut concerning credit spread risk is also calculated separately for each issue in a whole portfolio. It depends on the projected paths of the swap curve and government yield curve in the scenario and also on the credit rating and residual

7 According to the Basel LCR, the amount of inflows that can offset outflows should be capped at $75 \%$ of expected outflows in the standard. In other words, the minimum liquid asset buffer equals $25 \%$ of the total expected outflows (BCBS, 2013a). 
maturity of the issue. Generally, a higher devaluation rate corresponds to lower rating and longer residual maturity. Details concerning calculation techniques of the interest rate risk can be found in CNB (2017b). Cash and claims on the central bank are not subject to haircuts.

The size of the haircut applied to the expected inflow $(p)$ reflects the risk of the bank not receiving the full expected inflow. The haircuts are determined by counterparty risk and/or collateralisation of claims. Inflows from due mortgage loans and other inflows from due unsecured claims on households, non-financial corporations, credit institutions and other financial institutions are subject to other haircuts. The haircut applied to the inflow from unsecured loans to households and non-financial corporations is a function of the probability of default (PD) and the expected loss given default (LGD). PD and LGD are modelled using satellite models in bank solvency macro-stress tests. In those models, PD and LGD are a function of macroeconomic variables (for a detailed description, see Geršl et al., 2012).Claims on other banks are not subject to a haircut, as failure of the bank is implicitly assumed even in the event of partial default on such claims.

The run-off or draw-down parameter $(r)$ reflects the fact that due liabilities or credit commitments do not always lead to an outflow to the full extent. The value of credit lines, debt securities issued by the bank, retail deposits and wholesale funding is multiplied by this parameter. Debt securities issued by the bank and due in the given band are included in the liquidity outflow to the full extent, i.e., their rate of outflow is equal to one. In simple terms, it is assumed in the model that this source will not be restored in the next period. So, all issued debt securities with maturities of up to one year gradually mature over the test horizon.

In determining the run-off rate, account is taken of the type of counterparty and the stability of this funding source. The presented test follows basic principles used in the Basel LCR and NSFR standards, under which longer-term, more stable and easier-to-restore funding sources are subject to a lower run-off rate. A prominent finding in the literature is that a deposit's insurance status is the most important characteristic in determining the sensitivity of deposit flows (BCBS, 2013c). Therefore, we applied the lowest rate to insured retail deposits and the highest to unsecured wholesale funding. In the presented test, the run-off rate is composed of two values. The first is a benchmark. To set the benchmark, we followed the outflow factors for the relevant liabilities applied in the LCR requirement, for instance for insured retail deposits the benchmark is set to $2.5 \%$, for uninsured retail deposits to $5 \%$, for secured wholesale funding to $10 \%$ (funding from central bank included), for unsecured wholesale funding provided by non-financial corporations to $20 \%$, and for unsecured wholesale funding provided by financial institutions to $25 \%$. The second part of the value is an add-on linked to the capital ratio results from 
bank solvency macro-stress tests. The procedure is that the bank first undergoes a stress test of credit risk, which materializes and is reflected in a decrease in the capital ratio. The larger the decline in the overall capital ratio in the given quarter recorded by the bank, the larger the add-on to the outflow rate in the relevant maturity band. It is assumed that a larger decline in the capital ratio reflects larger losses or a higher overall level of risk, exposing the bank to larger liquidity outflows. The add-ons are set for each bank as follows: a decline in the capital ratio of $-1 \%$ corresponds to an add-on of $0.25 \%$, between $-1 \%$ and $-3 \%$ to an add-on of $0.5 \%$, and above $-3 \%$ to an add-on of $1 \%$.

Whereas the expected inflows are aggregately capped, net outflows are always positive. Therefore, in the next step, the banks concerned are assumed to react to the shocks. The bank tries to close the gap between outflows and inflows by using some sort of asset from its liquidity asset buffer. The model assumes minimisation of transaction losses. The bank therefore uses firstly assets to which the lowest haircut is assigned according to the scenario. ${ }^{8}$

Two situations can arise when the bank reacts. In the first case, the liquidity buffer $(L R)$ is sufficient to cover the net outflows. The size of the bank's reaction $(R)$ is thus smaller than or equal to its liquidity asset buffer reduced by a haircut (Equation 4) and the liquidity indicator for the relevant maturity band is higher than or equal to 1 :

$$
R_{Q t i}^{b} \leq L R_{Q t i}^{b}, \text { if } L R_{Q t i}^{b} \geq N e t O U T_{Q t}^{b} .
$$

In the second case, where the bank is hit more seriously by a wave of shocks, its liquidity asset buffer is not

sufficient to cover the net outflow in the given maturity band (Equation 5) and the liquidity indicator for that maturity band is smaller than 1. In such a situation, the bank's reaction is equal to the liquidity asset buffer. The entire liquidity buffer is exhausted, i.e., the bank has a deficit liquidity position?:

$$
R_{Q t i}^{b}=L R_{Q t i}^{b}, \text { if } L R_{Q t i}^{b}<N e t O U T_{Q t}^{b} .
$$

The result of the bank's reaction is that a stock of unencumbered assets included in the liquid asset buffer will be reduced. On the one hand, the reaction may mitigate the impact of the shock on balance-sheet liquidity, but on the other, it increases each

8 In reality, the bank may first try to sell off or pledge lower-quality assets even though they are subject to large market haircuts. The assumption of minimum transaction losses was chosen because the presen-ted approach aims at testing the adequacy of a bank's liquidity buffer in relation to the maturity mismatch in its balance sheet.

9 The liquidity position can be improved by accepting a short-term loan from another bank. Such "assistance" is not considered in the test given the assumption of a limit on the increase in funds. This does not apply to banks in a liquidity subgroup. 
reacting bank's reputational risk as well as raising systemic risk via the simultaneous reaction of banks on financial markets. Systemic risk rises if banks exert excessive unilateral pressure on the financial market (for example, if all banks try to sell the same type of bond), leading to a fall in market liquidity. Reputational risk consists in the signalling of problems with a bank's liquidity. The growth in these two risks then feeds back in the form of a second-round shock to banks' balance sheets. The third step therefore involves calculating and applying the feedback effect in the form of an additional market shock caused by banks' reactions. This endogenous systemic shock manifests itself as an additional haircut on the asset $(q)$ held in the liquidity buffer. We differentiate between the impact of systemic risk on non-reacting banks (qbnon) and that of systemic risk plus reputational risk on reacting banks (qbreac):

$$
q_{Q t i}^{\text {bnom }}=h_{Q t i}^{* b} *\left(\sum_{b} B\right)\left(\frac{\left(1+\frac{\sum_{b} R_{Q t i}^{b}}{\sum_{i} \sum_{b} R_{Q t i}^{b}}\right) s}{\sum_{b} B}\right) \text {, where } t=1,2,3,4,
$$

where $q \in\left\langle h^{*}, 1\right\rangle$ and $h^{*}$ reflect the market liquidity risk associated with the asset (see below), $s$ is a market conditions indicator and $B$ is a parameter equal to one if the bank is a reacting bank and zero if it is a non-reacting bank. A non-reacting bank is a bank that closes the gap between outflows and inflows by using cash or claims on the central bank. Those two liquid assets are not subject to haircuts and their use has no impact on markets. For parameter $h *$, the model uses the original haircut applied in the previous round of the test (h). ${ }^{10}$ The size of the additional haircut depends on the number of reacting banks $\left(\Sigma_{b} B\right)$ and the size and similarity of their reaction $\left(\sum_{b} R_{Q i}{ }^{b}\right)$. It is assumed that a larger number of similarly reacting banks causes greater market stress and hence a larger additional market shock. The market conditions indicator $(s)$ in the model expresses risk aversion. This indicator is derived from the standardised distribution of risk aversion indicators using implied stock price volatility and bond spreads as proxies (van den End, 2008). The indicator takes values in the range of $\langle-1,1\rangle$ under normal market conditions and up to 3 at times of high market stress. A higher market stress indicator magnifies the effect of the simultaneous reaction of banks. It is set by expert judgement based on knowledge of volatility and liquidity on the market concerned.

Reacting banks face reputational as well as systemic risk. In their case, the additional haircut is thus larger. This type of risk (like systemic risk) is expressed using a market

10 If $h$ is zero, the haircut on government bonds, then we use the haircut applied to the asset type in the NSFR requirement, see Assets assigned a 5\% RSF factor in BCBS, 2014, p. 11. 
conditions indicator, since the signalling effect of reacting banks has a large feedback effect in the event of market stress.

$$
q_{Q t i}^{\text {breac }}=q_{Q t i}^{\text {bnom }} \sqrt{s}, \text { where } t=1,2,3,4
$$

In a crisis, illiquid financial institutions - due to either prudential (liquidity-hoarding) or speculative (predatory) ${ }^{11}$ motives - are driven out of private credit markets or are granted liquidity at punitive rates. It is assumed in the methodology that the impacts of the shocks applied to the first maturity band and the subsequent reactions of banks will pass through to connected bands in the individual steps of the test $(Q=2,3,4)$. Here again, we consider an exogenous wave of shocks that affects the value of the assets held in the liquidity asset buffer and the size of the liquidity flows via $h, r$ and $p$. Additionally, however, we take into account the market stress caused by reacting banks $(q) .{ }^{12}$ The liquidity indicator thus changes as follows:

$$
L I_{Q t}^{b}=\frac{\sum_{i} L A_{Q i t}^{b}\left(1-h_{Q t i}^{b}-q_{Q t-1 i}^{b}\right)}{N e t O U T_{Q t}^{b}}, \text { where } t=1,2,3,4 .
$$

It is clear that the model has limitations that prevent it from fully capturing the liquidity risk that a tested banking sector may face. For instance, it fails to take into consideration that the provision and repayment of loans are closely bound up with the creation and termination of deposits. In the test, the liquidity position of banks is improved by loan repayments (inflow) but no longer shows up as deposit termination (outflow). The model also fails to take account of direct interbank contagion, an interaction with non-bank financial intermediaries and hence the potential domino effect. The scenario considers only a simplified general interest rate shock based on the evolution of government yield curves, and only in two currencies. Specific interest rate risk is captured only endogenously through banks' reaction functions. Exchange rate risk and real estate risk are not considered at all. The model does not distinguish the type of credit and liquid lines in relation to the counterparty, i.e., it does not work with intragroup liquidity lines. A more relevant limitation is that the model takes into account only one type of banking reaction and does not work with a banking reaction through changes in interest rates for example. The liquidity stress test should be further refined in these areas.

11 This is a speculative motive based on the assumption that high demand for cash implies low asset prices. In a crisis, when some banks are in a difficult liquidity situation, liquid banks may use their market strength and curb the provision of liquidity to illiquid banks or raise the price of that liquidity for purely strategic, healthy competition reasons. If loan rates are too high, an illiquid bank is forced to sell off its assets, often at very attractive prices (i.e., it falls prey to predators).

12 The additional haircut is applied to assets available for sale in the portfolio. In the case of bonds held to maturity, the additional haircut is only applied to the part used as collateral. 


\section{Application of the Approach to Selected Czech Banks}

The methodology described above was applied to a representative sample of 19 banks domiciled in the Czech Republic, with various business models and bank sizes represented. The main objective was to monitor the sensitivity of the liquidity position of selected banks to a combination of shocks under the given methodology. The application was conducted on end-of-2016 data for the banks under review. The data were obtained from the CNB's statistics. The CNB's November 2016 macro-stress scenario and macro-stress test results (CNB, 2016b) were used to simulate the bulk of the exogenous shocks. The parameters of the exogenous shocks are summarised in Table 1. The parameters of the shocks, including the endogenous ones, are summarised in Table 2 in the Appendix. We opted for a single market indicator (s) of 1.5, implying low market liquidity (van den End, 2008).

The liquidity asset buffer $(L R)$ was defined for the test as the weighted sum of cash, claims on the central bank (excluding minimum reserves), debt securities issued by domestic and foreign governments, capital instruments and corporate debt securities excluding those held in credit portfolios. ${ }^{13}$

On the aggregate level, the liquidity indicator $(L I)$ stayed high for two bank types after the shocks were applied. Building societies had the highest indicator and small banks the second-highest (see Figure 1). For building societies, this was due to lower net outflows (NetOUT), while for small banks it was due to a relatively high initial liquidity asset buffer (see Figure 2). A smaller impact is apparent for building societies (a decline in the total liquidity asset buffer of around 55\%). We compared the liquidity indicators of banking groups with their LCR requirement (Figure 1). Given the monthly horizon of the stress considered in the case of the LCR, the highest aggregate LCR was achieved for building societies, which, compared to the other groups of banks, have a significantly lower share of deposits to which a higher run-off rate is applied in the LCR requirement. This confirms that the LCR requirement as a short-term stress test is inappropriate for testing these types of business models such as building societies. Universal banks - represented mainly by large banks - recorded the largest decline in the overall liquidity asset buffer $(L R)$ over four quarters (around $75 \%$ ). This decline was caused primarily by large net outflows (NetOUT), as their liquidity asset buffer is made up mainly of high-quality liquid assets $(i)$, which are subject to small or zero haircuts $(h)$. The liquidity indicator fell below the $100 \%$ minimum in the case of large and medium-sized banks, although not before the last quarter.

13 Collateral accepted was not included in the buffer due to data unavailability. 
Table 1: Liquidity stress test scenario (\%)

\begin{tabular}{|c|c|c|c|c|c|c|}
\hline \multicolumn{3}{|c|}{ Balance-sheet item / Maturity bands } & $<3 \mathrm{M}$ & $3 M-6 M$ & $6 M-9 M$ & $9 M-12 M$ \\
\hline \multicolumn{3}{|c|}{ 1. Liquidity asset buffer } & \multicolumn{4}{|c|}{ Interest rate and equity shock } \\
\hline \multirow[t]{5}{*}{1.1} & \multicolumn{6}{|c|}{ Q-o-q change in yield curve ${ }^{13}$ in pp* $^{*}$} \\
\hline & & 1Y PRIBOR & 0.3 & 0.0 & 0.0 & 0.0 \\
\hline & & $5 Y$ GB yield & 1.0 & 0.6 & 0.5 & 0.4 \\
\hline & & 1Y EURIBOR & 0.2 & 0.0 & 0.0 & 0.0 \\
\hline & & 5Y EUR GB yield & 0.0 & 0.2 & 0.3 & 0.2 \\
\hline 1.2 & \multicolumn{2}{|c|}{ Haircuts from value of capital instrument ${ }^{14}$} & 30.0 & - & - & - \\
\hline \multicolumn{3}{|c|}{ 2. Inflows } & \multicolumn{4}{|c|}{ Size of deduction from expected inflow } \\
\hline 2.1 & Secured claims & & 0.9 & 0.9 & 0.9 & 0.9 \\
\hline \multirow[t]{3}{*}{2.2} & \multicolumn{6}{|l|}{ Unsecured claims due ${ }^{* *}$} \\
\hline & & on NPs & 2.1 & 2.2 & 2.4 & 2.6 \\
\hline & & on NFCs and retail SMEs & 1.1 & 1.2 & 1.2 & 1.2 \\
\hline \multicolumn{3}{|c|}{ 3. Outflows } & \multicolumn{4}{|c|}{ Expected outflow rate } \\
\hline 3.1 & \multicolumn{2}{|l|}{ Drawdown of credit lines } & 5.0 & 5.0 & 5.0 & 5.0 \\
\hline 3.2 & \multicolumn{2}{|l|}{ Issued debt securities } & 100.0 & 100.0 & 100.0 & 100.0 \\
\hline \multirow[t]{3}{*}{3.3} & \multicolumn{6}{|l|}{ Retail deposits $^{15}$} \\
\hline & & insured & 3.2 & 3.5 & 3.2 & 3.1 \\
\hline & & others & 6.3 & 7.0 & 6.4 & 6.3 \\
\hline \multirow[t]{3}{*}{3.4} & \multicolumn{6}{|l|}{ Liabilities to NFC } \\
\hline & & insured & 12.6 & 14.1 & 12.9 & 12.5 \\
\hline & & others & 25.3 & 28.2 & 25.8 & 25.0 \\
\hline \multirow[t]{3}{*}{3.5} & \multicolumn{6}{|l|}{ Liabilities to Fls } \\
\hline & & insured & 12.6 & 14.1 & 12.9 & 12.5 \\
\hline & & others & 31.6 & 35.2 & 32.2 & 31.3 \\
\hline \multirow[t]{4}{*}{3.6} & \multicolumn{6}{|c|}{ Growth in new loans ${ }^{16}$, of which ${ }^{* * *}$} \\
\hline & & secured claims & 0.0 & 1.4 & 1.3 & 1.0 \\
\hline & & due to NPs & 0.0 & 1.0 & 0.6 & 0.4 \\
\hline & & due to NFCs and retail SMEs & 2.4 & 0.0 & 0.7 & 0.0 \\
\hline
\end{tabular}

Note: The parameter values are the averages of those applied to individual banks. *The haircut is determined by multiplying the change in the yield curve by the duration of the bond portfolio. ** Due claims on financial institutions were not subject to deductions in this scenario. ${ }^{* * *}$ The credit growth assumption is calculated using satellite models in macro stress tests of bank solvency. NFCs: non-financial corporations, Fls: financial institutions, NPs: natural persons. This table does not contain the endogenous (systemic and reputational) shocks generated in the second round of shocks.

Source: CNB, authors' calculations

14 We assume a shock to the five-year government bond rate as a result of growth in global risk aversion and reassessment of the safety of certain assets. Other rates (other maturities, IRS) are then modelled consistently with the five-year government bond using a dynamic factor model (Diebold et al., 2006).

15 The equity shock had to be set by expert judgement.

16 In the months prior to failure, most insured account types experienced a run-off in the 10 to $20 \%$ range (BCBS, 2013c).

17 Outflows include new loans, which are assumed to have maturities over one year. The credit growth assumption is computed using satellite models in solvency macro-stress tests (Geršl et al., 2012). 
Figure 1: Post-stress liquidity indicators

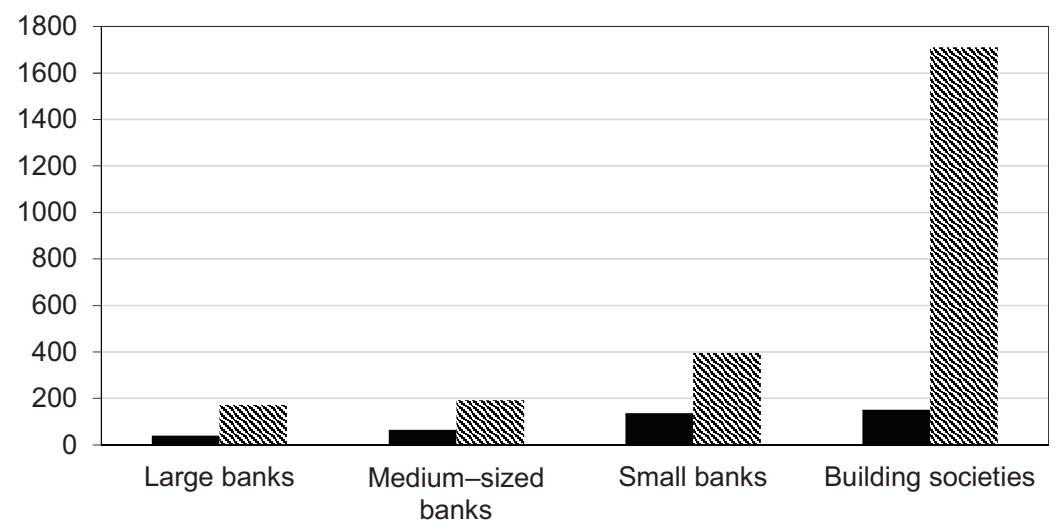

- Liquidity indicators after one-year stress period

*LCR (one-month stress period)

Note: end-2016 data

Source: CNB, authors' calculations

Figure 2: Results of the one-year horizon liquidity stress test ( $\%$ of balance sheet total of bank type)

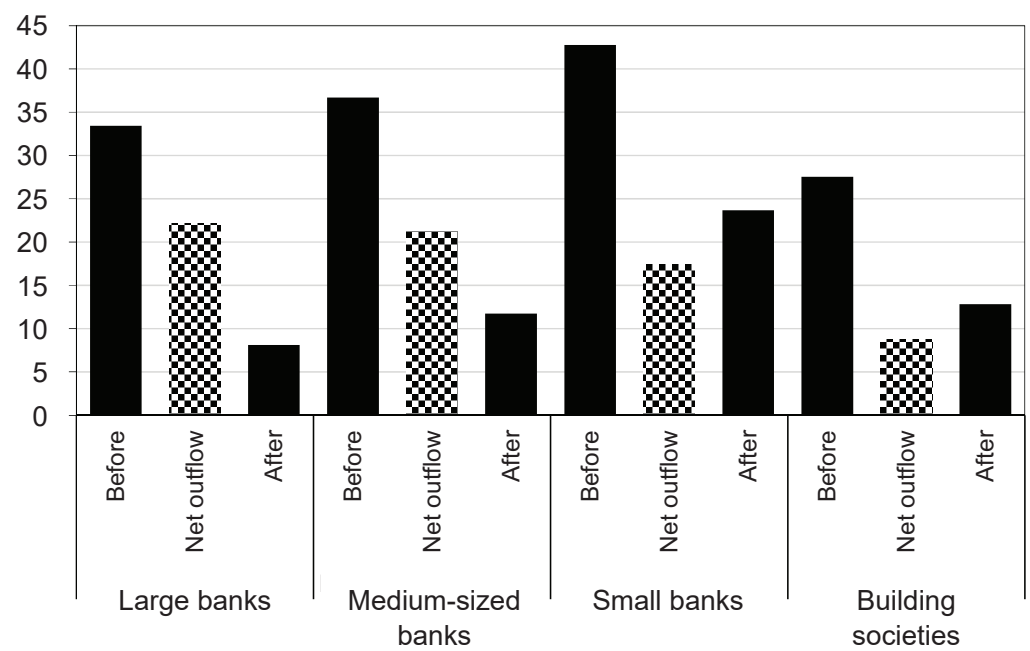

Note: end-2016 data. The column "Before" represents the pre-stress size of the liquidity buffer and the column "After" the post-stress size of the liquidity buffer. The column "Net outflow" represents the outflow of liquidity over the one-year horizon.

Source: CNB, authors' calculations 
A few banks exhausted their entire liquidity asset buffers $(L R)$ during our one-year test, although the earliest this occurred was in the last quarter (see Figure 3). However, some of those banks specialise intentionally in a particular product type. They rely mostly on funding sources within their financial groups and hold hardly any liquid assets. However, the methodology also indicated that some universal banks have less stable sources in relation to their liquidity asset buffers $(L R)$. In the case of banks that did not exhaust their liquidity asset buffers $(L R)$, the liquidity indicator $(L I)$ gradually decreased as the maturity bands increased in length (see Figure 4). However, these banks are more than sufficiently compliant with the required indicator level $(L I)$ despite the fact that they had to use their liquidity asset buffers $(L R)$ to cover net outflows (NetOUT) from the very first round of the test.

Figure 3: Liquidity buffers of tested banks (\% of bank's balance sheet)

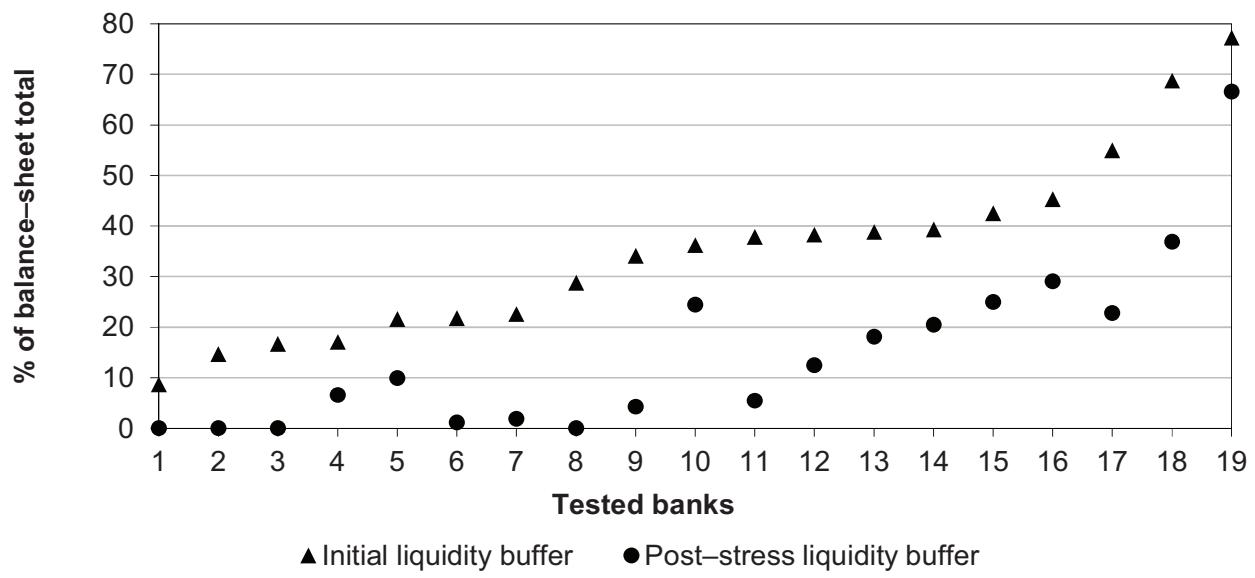

Note: end-2016 data

Source: CNB, authors' calculations

The source of resilience of most of the banks under review is their sufficient liquidity asset buffer (mostly 20\% of bank's assets, see Figure 3), which consists mostly of zerohaircut claims on the central bank and debt securities issued by domestic government. For the most part, government bonds are subject not to the interest rate shocks but only to the additional haircuts in the second round of shocks (see Appendix), since a large proportion of the banks under review hold them to maturity. ${ }^{18}$

18 In the case of bonds held to maturity, the additional haircut is only applied to the part used as collateral. 
Figure 4: Liquidity indicator profiles over the test period (\%)

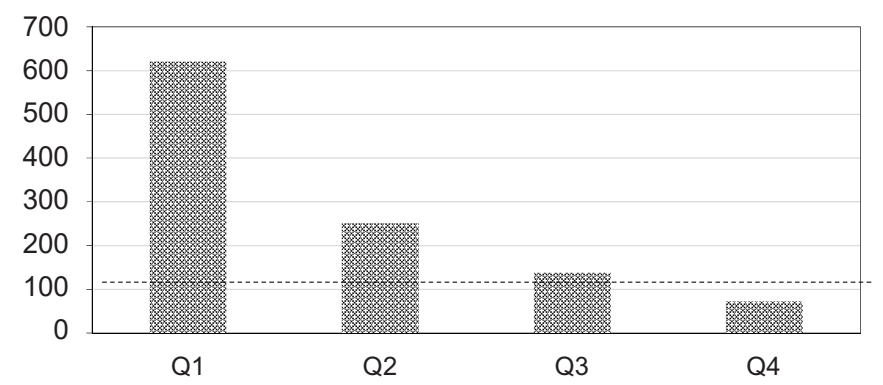

Note: end-2016 data

Source: CNB, authors' calculations

Figure 5: Liquidity inflow structure (\% of balance-sheet total of bank type; $x$-axis: maturity band)

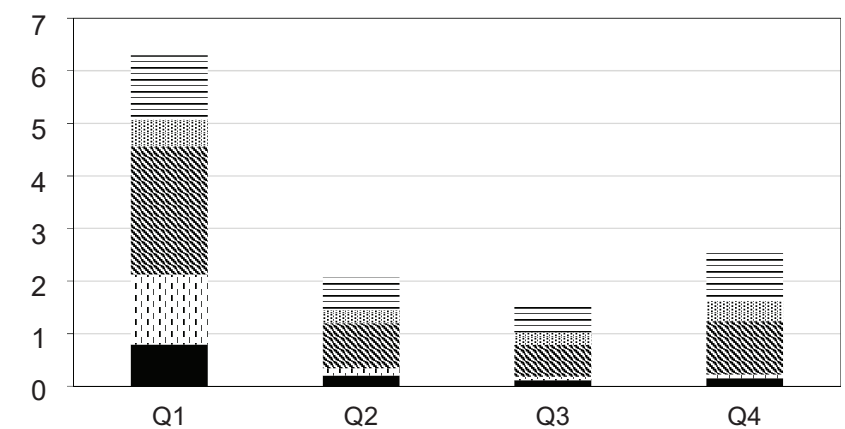

$\equiv$ Secured claims

\& Claims on non-financial corporations

Calims on individuals

!. Claims on credit institutions

- Claims on other financial institutions

Note: end -2016 data, $Q=$ maturity bands: of $0-3$ months, 3-6 months, $6-9$ months and 9-12 months. Source: CNB, authors' calculations

The liquidity asset buffer $(L R)$ is fairly homogeneous across the tested banking sector, a property that may magnify the drop in its value if it is used by a large set of banks. Paradoxically, the overall endogenous shock in the form of the additional haircut (see Appendix) on domestic government bonds may thus be large by comparison with riskier assets with lower shares in the liquidity asset buffer $(L R)$. On the one hand, a more 
diversified portfolio could mitigate this type of systemic risk. On the other hand, most market prices of assets are highly correlated during a crisis, so only cash or near-cash assets (such as claims on the central bank) can offer real hedging against such risk.

A more detailed breakdown reveals that claims on non-financial corporations, which banks usually provide with shorter maturities, make up the largest part of the inflows in all maturity bands. They therefore significantly exceed claims on individuals and credit institutions in maturities of one year or less (see Figure 5). Due to their very short maturities, inflows from claims on credit institutions are relevant only in the first maturity band of 0-3 months. By contrast, inflows from claims on households grow in importance with increasing maturity length. However, the one-year test period was too short for the simulated credit shocks to have a major impact via these claims.

Figure 6: Liquidity outflow structure (\% of balance-sheet total of bank type; $x$-axis: maturity band)

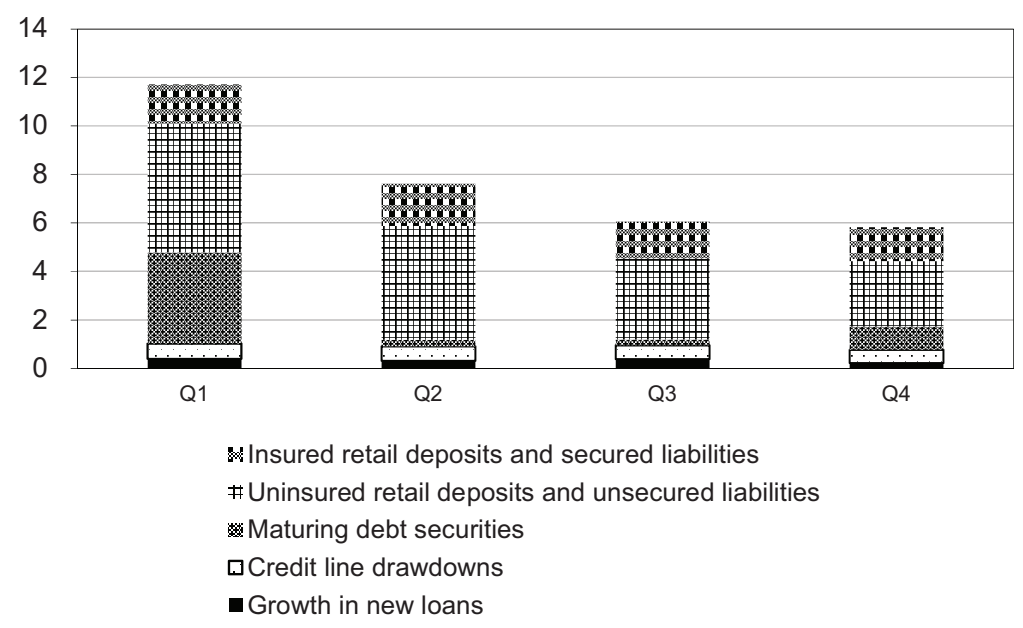

Note: end-2016 data, $\mathrm{Q}=$ maturity bands: of 0-3 months, 3-6 months, 6-9 months and 9-12 months. Source: CNB, authors' calculations

Uninsured retail deposits and unsecured liabilities to non-financial corporations and financial institutions dominate outflows at the aggregate level (see Figure 6). Outflows from relations with non-financial corporations far exceed those from other relations. There are two main reasons for this. The banks under review fund themselves primarily by accepting deposits from households and non-financial corporations rather than by obtaining loans from other banks on money markets. Compared to retail financing, 
however, corporate (wholesale) financing is considered a less stable funding source, so a relatively high outflow rate is applied to it. Banks whose sources consist mostly of corporate deposits therefore undergo severe stress in this test. Their liquidity buffers should thus be larger than those of banks with predominantly retail sources to survive the stress.

\section{Conclusion}

This article described a liquidity stress-testing framework based on some principles of two Basel liquidity regulatory standards: the LCR and the NSFR. The model took into account the impact of both bank-specific and market-wide scenarios and included second-round effects of shocks due to banks' feedback reactions with an endogenous adverse feedback loop. We also showed how solvency and liquidity stress-testing frameworks can be interlinked, so that a complete stress-testing exercise can encompass mutually consistent shocks to liquidity, market, credit and other risks. The survival period was set to one year to monitor the liquidity position of banks over a longer period of market stress.

The output of the presented stress test is a liquidity indicator which, analogously to the LCR, expresses the coverage of the net expected liquidity outflow with liquid assets subject to haircuts. The liquidity indicator level is deemed adequate if it maintains a minimum value of one over a one-year period (analogously to the NSFR). The stress test methodology was applied to a representative sample of 19 banks domiciled in the Czech Republic, with various business models and bank sizes represented. The sole aim of the analysis - based on real data - was to present the methodology and monitor the sensitivity of the liquidity position of selected banks to a combination of shocks considered over a longer period.

The outcomes of the model showed that most of the Czech banks seemed to be resilient against presumed liquidity, market and credit shocks. However, there were four of them that exhausted their liquidity buffers, partly also due to the second-round effects. Their liquidity indicators fell below the $100 \%$ minimum although not before the last quarter. This proved that there is heterogeneity among tested banks and that sufficient liquidity in a banking sector as a whole can be specious. We also compared the liquidity indicators of banking groups with their LCR requirement. The results confirm that the LCR requirement as a short-term stress test is inappropriate for testing some types of business models such as building societies. It results that a shorter and a longer horizon should be explored in a stress test to assess whether a bank's outcomes are sensitive to this issue. 


\section{Appendix}

Table 2: Summary of parameter settings with use of the scenario (\%)

\begin{tabular}{|c|c|c|c|c|c|c|}
\hline \multirow[t]{2}{*}{ Balance-sheet item } & \multirow[t]{2}{*}{$\begin{array}{l}\text { Parameterisation } \\
\text { source }\end{array}$} & \multicolumn{4}{|c|}{ Parameter value for maturity band } & \multirow[t]{2}{*}{ Shock type } \\
\hline & & $\leq 3 \mathrm{M}$ & $>3 M-6 M$ & $>6 \mathrm{M}-9 \mathrm{M}$ & $>9 M-12 M$ & \\
\hline \multicolumn{7}{|c|}{ Inflows $(p)$} \\
\hline Secured claims & macro-stress scenario & 0.33 & 0.40 & 0.55 & 0.50 & credit \\
\hline \multicolumn{7}{|c|}{ Claims due* } \\
\hline on individuals & macro-stress scenario & 1.35 & 1.44 & 1.54 & 1.59 & credit \\
\hline $\begin{array}{l}\text { on non-financial customers } \\
\text { and retail SMEs }\end{array}$ & macro-stress scenario & 0.56 & 0.70 & 0.69 & 0.69 & credit \\
\hline
\end{tabular}

Liquidity buffer

\begin{tabular}{|c|c|c|c|c|c|c|}
\hline \multicolumn{7}{|c|}{ Interest rate shock to debt securities $(h)$} \\
\hline $\begin{array}{l}\text { Domestic government AFS } \\
\text { in CZK }\end{array}$ & macro-stress scenario & 4.31 & 2.96 & 4.43 & 1.06 & $\begin{array}{l}\text { market - interest } \\
\text { rate }\end{array}$ \\
\hline $\begin{array}{l}\text { Foreign government AFS } \\
\text { in CZK }\end{array}$ & macro-stress scenario & 7.05 & 4.79 & 7.19 & 1.71 & $\begin{array}{l}\text { market - interest } \\
\text { rate }\end{array}$ \\
\hline Domestic Cls' AFS in CZK & macro-stress scenario & 4.15 & 2.79 & 4.18 & 0.99 & $\begin{array}{l}\text { market - interest } \\
\text { rate }\end{array}$ \\
\hline Foreign Cls' AFS in CZK & macro-stress scenario & 1.45 & 0.94 & 1.40 & 0.33 & $\begin{array}{l}\text { market - interest } \\
\text { rate }\end{array}$ \\
\hline $\begin{array}{l}\text { Domestic corporations' AFS } \\
\text { in CZK }\end{array}$ & macro-stress scenario & 2.10 & 1.38 & 2.07 & 0.49 & $\begin{array}{l}\text { market - interest } \\
\text { rate }\end{array}$ \\
\hline $\begin{array}{l}\text { Foreign corporations' AFS } \\
\text { in CZK }\end{array}$ & macro-stress scenario & 0.68 & 0.38 & 0.57 & 0.14 & $\begin{array}{l}\text { market - interest } \\
\text { rate }\end{array}$ \\
\hline $\begin{array}{l}\text { Domestic government AFS } \\
\text { in foreign currency }\end{array}$ & macro-stress scenario & 0.84 & 0.76 & 1.19 & 0.63 & $\begin{array}{l}\text { market - interest } \\
\text { rate }\end{array}$ \\
\hline $\begin{array}{l}\text { Foreign government AFS } \\
\text { in foreign currency }\end{array}$ & macro-stress scenario & 0.81 & 0.69 & 1.08 & 0.57 & $\begin{array}{l}\text { market - interest } \\
\text { rate }\end{array}$ \\
\hline $\begin{array}{l}\text { Domestic Cls' AFS } \\
\text { in foreign currency }\end{array}$ & macro-stress scenario & 0.69 & 0.62 & 0.97 & 0.51 & $\begin{array}{l}\text { market - interest } \\
\text { rate }\end{array}$ \\
\hline $\begin{array}{l}\text { Foreign Cls' AFS in foreign } \\
\text { currency }\end{array}$ & macro-stress scenario & 0.37 & 0.25 & 0.40 & 0.21 & $\begin{array}{l}\text { market - interest } \\
\text { rate }\end{array}$ \\
\hline $\begin{array}{l}\text { Domestic corporations' AFS } \\
\text { in foreign currency }\end{array}$ & macro-stress scenario & 0.79 & 0.76 & 1.18 & 0.62 & $\begin{array}{l}\text { market - interest } \\
\text { rate }\end{array}$ \\
\hline $\begin{array}{l}\text { Foreign corporations' AFS } \\
\text { in foreign currency }\end{array}$ & macro-stress scenario & 0.88 & 0.78 & 1.22 & 0.65 & $\begin{array}{l}\text { market - interest } \\
\text { rate }\end{array}$ \\
\hline \multicolumn{7}{|c|}{ Endogenous market liquidity shocks (r/n) } \\
\hline Capital instruments $(h)$ & liquidity stress test & $61.24 / 50.00$ & $78.30 / 63.93$ & 77.94 / 63.64 & $61.24 / 50.00$ & $\begin{array}{l}\text { market - systemic } \\
\text { and reputational }\end{array}$ \\
\hline Capital instruments $(q)$ & liquidity stress test & $11.24 / 0.00$ & $28.30 / 13.93$ & $41.87 / 29.83$ & $-/ 30.59$ & $\begin{array}{l}\text { market - systemic } \\
\text { and reputational }\end{array}$ \\
\hline $\begin{array}{l}\text { Debt securities of domestic } \\
\text { government }(h)\end{array}$ & liquidity stress test & $16.44 / 13.43$ & $9.48 / 7.74$ & $9.38 / 7.66$ & $10.40 / 8.49$ & $\begin{array}{l}\text { market - systemic } \\
\text { and reputational }\end{array}$ \\
\hline $\begin{array}{l}\text { Debt securities of domestic } \\
\text { government }(q)\end{array}$ & liquidity stress test & $11.44 / 8.43$ & $12.91 / 11.37$ & $16.71 / 14.10$ & $22.25 / 18.24$ & $\begin{array}{l}\text { market - systemic } \\
\text { and reputational }\end{array}$ \\
\hline $\begin{array}{l}\text { Debt securities of foreign } \\
\text { government }(h)\end{array}$ & liquidity stress test & $6.12 / 5.00$ & $7.90 / 6.45$ & $8.14 / 6.65$ & $8.37 / 6.84$ & $\begin{array}{l}\text { market - systemic } \\
\text { and reputational }\end{array}$ \\
\hline
\end{tabular}


Table 2 (continued)

\begin{tabular}{|c|c|c|c|c|c|c|}
\hline $\begin{array}{l}\text { Debt securities of foreign } \\
\text { government }(q)\end{array}$ & liquidity stress test & $1.12 / 0.00$ & $2.90 / 1.45$ & $5.07 / 3.18$ & $7.21 / 5.28$ & $\begin{array}{l}\text { market - systemic } \\
\text { and reputational }\end{array}$ \\
\hline $\begin{array}{l}\text { Debt securities of domestic } \\
\text { Cls }(h)\end{array}$ & liquidity stress test & $62.36 / 50.92$ & $47.80 / 39.03$ & $47.03 / 38.40$ & $51.53 / 42.07$ & $\begin{array}{l}\text { market - systemic } \\
\text { and reputational }\end{array}$ \\
\hline $\begin{array}{l}\text { Debt securities of domestic } \\
\text { Cls }(q)\end{array}$ & liquidity stress test & $32.36 / 20.92$ & 38.72 / 30.55 & 46.97 / 39.95 & $59.87 / 52.46$ & $\begin{array}{l}\text { market - systemic } \\
\text { and reputational }\end{array}$ \\
\hline $\begin{array}{l}\text { Debt securities of foreign } \\
\text { Cls }(h)\end{array}$ & liquidity stress test & $63.09 / 51.51$ & 46.82 / 38.23 & $46.79 / 38.20$ & $49.42 / 40.35$ & $\begin{array}{l}\text { market - systemic } \\
\text { and reputational }\end{array}$ \\
\hline $\begin{array}{l}\text { Debt securities of foreign } \\
\text { Cls }(q)\end{array}$ & liquidity stress test & $33.09 / 21.51$ & 44.12 / 29.74 & $46.53 / 39.45$ & $57.36 / 49.25$ & $\begin{array}{l}\text { market - systemic } \\
\text { and reputational }\end{array}$ \\
\hline $\begin{array}{l}\text { Debt securities of domestic } \\
\text { zcorporations }(h)\end{array}$ & liquidity stress test & $63.17 / 51.58$ & $46.86 / 38.26$ & $46.88 / 38.28$ & $49.52 / 40.43$ & $\begin{array}{l}\text { market - systemic } \\
\text { and reputational }\end{array}$ \\
\hline $\begin{array}{l}\text { Debt securities of domestic } \\
\text { corporations }(q)\end{array}$ & liquidity stress test & $33.17 / 21.58$ & $38.43 / 30.45$ & 46.72 / 39.63 & $57.64 / 50.07$ & $\begin{array}{l}\text { market - systemic } \\
\text { and reputational }\end{array}$ \\
\hline $\begin{array}{l}\text { Debt securities of foreign } \\
\text { corporations }(h)\end{array}$ & liquidity stress test & $36.74 / 30.00$ & $46.75 / 38.17$ & $46.83 / 38.24$ & $49.44 / 40.36$ & $\begin{array}{l}\text { market - systemic } \\
\text { and reputational }\end{array}$ \\
\hline $\begin{array}{l}\text { Debt securities of foreign } \\
\text { corporations }(q)\end{array}$ & liquidity stress test & $6.74 / 0.00$ & $16.75 / 8.17$ & $25.00 / 16.86$ & $35.84 / 27.78$ & $\begin{array}{l}\text { market - systemic } \\
\text { and reputational }\end{array}$ \\
\hline \multicolumn{7}{|c|}{ Outflows (r) } \\
\hline Credit line drawdowns** & expert judgement & 5 & 5 & 5 & 5 & liquidity \\
\hline Debt securities issued & $\begin{array}{l}\text { non-restoration } \\
\text { of source assumed }\end{array}$ & 100 & 100 & 100 & 100 & liquidity \\
\hline \multicolumn{7}{|c|}{ Retail deposits } \\
\hline insured & $\begin{array}{l}\text { LCR floor, macro-stress } \\
\text { test, CAR }\end{array}$ & 3.75 & 3.75 & 3.12 & 3.75 & liquidity \\
\hline other & $\begin{array}{l}\text { LCR floor, macro-stress } \\
\text { test, CAR }\end{array}$ & 7.50 & 7.50 & 6.25 & 7.50 & liquidity \\
\hline \multicolumn{7}{|c|}{ Liabilities to NFCs } \\
\hline secured & $\begin{array}{l}\text { LCR floor, macro-stress } \\
\text { test, CAR }\end{array}$ & 15 & 15 & 12.50 & 15 & liquidity \\
\hline other & $\begin{array}{l}\text { LCR floor, macro-stress } \\
\text { test, CAR }\end{array}$ & 30 & 30 & 25 & 30 & liquidity \\
\hline \multicolumn{7}{|c|}{ Liabilities to Fls } \\
\hline secured & $\begin{array}{l}\text { LCR floor, macro-stress } \\
\text { test, CAR }\end{array}$ & 15 & 15 & 12.50 & 15 & liquidity \\
\hline other & $\begin{array}{l}\text { LCR floor, macro-stress } \\
\text { test, CAR }\end{array}$ & 37.50 & 37.50 & 31.25 & 37.50 & liquidity \\
\hline \multicolumn{7}{|c|}{ Growth in new loans } \\
\hline of which secured claims & macro-stress scenario & 0.40 & 0 & 1.50 & 0.90 & credit \\
\hline $\begin{array}{l}\text { of which due vis-à-vis } \\
\text { individuals }\end{array}$ & macro-stress scenario & 0 & 0 & 0 & 0 & credit \\
\hline $\begin{array}{l}\text { of which due vis-à-vis } \\
\text { non-financial customers } \\
\text { and retail SMEs }\end{array}$ & macro-stress scenario & 1.20 & 0 & 0 & 0.60 & credit \\
\hline
\end{tabular}

Note: $(r / n)$ stands for reacting/non-reacting bank, $h$ for the haircut on a liquid asset, $p$ for the size of the haircut on the expected inflow and $r$ for the size of the outflow. The parameter values are the average parameter values applied to individual banks. * Due claims on financial institutions were not subject to haircuts in this scenario. ${ }^{* *}$ The stock of credit lines as of the test date was multiplied by the value of this expertly set parameter.

Source: CNB, authors' calculations 


\section{References}

Aikman, D., Alessandri, B., Eklund, B., Gai, P., Kapadia, S., Martin, E., Mora, N., Sterne, G., Willison, M. (2009). Funding Liquidity Risk in a Quantitative Model of Systemic Stability. Bank of England. Working Paper No. 372, https://doi.org/10.2139/ssrn.1420062

Alessandri, P., Gai, P., Kapadia, S., Mora, N., Puhr, C. (2009). Towards a Framework for Quantifying Systemic Stability. International Journal of Central Banking, 5(3), 47-81.

Allen, F., Gale, D. (2000). Financial Contagion. Journal of Political Economy, 108(1), 1-33, https://doi.org/10.1086/262109

Andrle, M., Hlédit, T., Kameník, O., Vlček, J. (2009). Implementing the New Structural Model of the Czech National Bank. CNB. Working Paper No. 2009/2.

Bank of Korea (2012). Systemic Risk Assessment Model for Macroprudential Policy (SAMP), in BoK, Financial Stability Report. Seoul: Bank of Korea.

BCBS (2013a). Basel III: The Liquidity Coverage Ratio and Liquidity Risk Monitoring Tools. BIS Consultative Document.

BCBS (2013b). Liquidity Stress Testing: a Survey of Theory, Empirics and Current Industry and Supervisory Practices. BIS. Working Paper No. 24.

BCBS (2013c). Literature Review of Factors Relating to Liquidity Stress - Extended Version. BIS. Working Paper No. 25.

BCBS (2014). Basel III: The Net Stable Funding Ratio. BIS Consultative Document.

BIS (2015). Making Supervisory Stress Tests More Macroprudential: Considering Liquidity and Solvency Interactions and Systemic Risk. BIS. Working Paper No. 29.

Boss, M., Krenn, G., Puhr, C., Summer, M. (2006). Systemic Risk Monitor: a Model for Systemic Risk Analysis and Stress Testing of Banking Systems. OeNB. Financial stability Report No. 11.

Brázdik, F., Hlaváček, M., Maršál, A. (2011). Survey of Research on Financial Sector Modeling within DSGE Models: What Central Banks Can Learn from It. CNB. Research and Policy Note No. 3/2011.

Cetina, J. (2015). Incorporating Liquidity Shocks and Feedbacks in Bank Stress Tests. OFR. Brief Series No. 15-06.

Cifuentes, R., Gerrucci, G., Shin, H. (2005). Liquidity Risk and Contagion. Journal of the European Economic Association, 3(2-3), 556-566, https://doi.org/10.1162/ jeea.2005.3.2-3.556

CNB (2008). Financial Stability Report 2007. Prague: Czech National Bank.

CNB (2009). Financial Stability Report 2008/2009. Prague: Czech National Bank.

CNB (2010). Financial Stability Report 2009/2010. Prague: Czech National Bank.

CNB (2011). Financial Stability Report 2010/2011. Prague: Czech National Bank.

CNB (2012). Financial Stability Report 2011/2012. Prague: Czech National Bank.

CNB (2013). Financial Stability Report 2012/2013. Prague: Czech National Bank. 
CNB (2014). Financial Stability Report 2013/2014. Prague: Czech National Bank. CNB (2015a). Financial Stability Report 2014/2015. Prague: Czech National Bank. CNB (2016a). Financial Stability Report 2015/2016. Prague: Czech National Bank.

CNB (2016b). Banking Sector Stress Tests. Available at: http://www.cnb.cz/miranda2/ export/sites/www.cnb.cz/cs/financni_stabilita/zatezove_testy/2016/zatezo ve_testy_ vysledky_2016_3q.pdf

CNB (2017a). Financial Stability Report 2016/2017. Prague: Czech National Bank.

CNB (2017b). Macro-stress Tests of the Pension Management Companies Sector. Available at: http://www.cnb.cz/miranda2/export/sites/www.cnb.cz/en/financial_stability/stress_ testing/download/st ress_testing_FPS_methodology.pdf

Čihák, M. (2007). Introduction to Applied Stress Testing. IMF. Working Paper No. 7.

Diebold, F. X., Rudebusch, G., Aruoba, S. B. (2006). The Macroeconomy and the Yield Curve:

A Dynamic Latent Factor Approach. Journal of Econometrics, 131(1-2), 309-338, https://doi.org/10.1016/j.jeconom.2005.01.011

EBA (2019). Update on the EBA Report on Liquidity Measures under Article 509(1) of the CRR results based on data as of 30 June. EBA. March 2019.

Gauthier, C., Souissi, M. (2010). Understanding Systemic Risk: The Trade-Offs between Capital, Short-Term Funding and Liquidity Asset Holdings. Bank of Canada. Working Paper No. 29.

Geršl, A., Jakubík, P., Konečný, T., Seidler, J. (2012). Dynamic Stress Testing: The Framework for Testing Banking Sector Resilience Used by the Czech National Bank. Czech National Bank. Working Paper No. 11.

Geršl, A., Komárková, Z., Komárek, L. (2016). Liquidity Stress Testing with Second-Round Effects: Application to the Czech Banking Sector. Czech Journal of Economics and Finance, 66(1), 32-49.

Heider, F., Hoerova, M., Holthausen, C. (2015). Liquidity Hoarding and Interbank Market Spreads: The Role of Counterparty Risk. Journal of Financial Economics, 118(2), 336-354, https://doi.org/10.1016/j.jfineco.2015.07.002

Hlaváček, M., Komárek, L. (2009). Housing Price Bubbles and their Determinants in the Czech Republic and its Regions. CNB. Working Paper No. 2009/12.

Horváth, R., Seidler, J., Weill, L. (2014). Bank Capital and Liquidity Creation: Granger-causality Evidence. Journal of Financial Services Research, 45(3), 341-361, https://doi.org/10.1007/ s10693-013-0164-4

Komárková, Z., Geršl, A., Komárek, L. (2011). Models for Stress Testing Czech Banks' Liquidity Risk, Czech National Bank. CNB. Working Paper No. 11.

Komárková, Z., Rusnák, M., Hejlová, H. (2016). The Relationship between Liquidity Risk and Credit Risk in the CNB's Liquidity Stress Tests. Financial Stability Report 2015/2016.

Kučera, A., Dvořák, M., Komárková, Z. (2019). The Czech Government Yield Curve Decomposition at the Lower Bound. Czech Journal of Economics and Finance, 69(1), 2-36. 
Nier, E., Yang, J., Yorulmazer, T., Alentorn, A. (2008). Network Models and Financial Stability. Bank of England. Working Paper No. 346, https://doi.org/10.2139/ssrn.1280788

Puhr, C., Schmitz, S. (2014). A View from the Top - The Interaction between Solvency and Liquidity Stress. Journal of Risk Management in Financial Institutions, 7(4), 38-51.

Puhr, C., Santos, A., Schmieder, Ch., Neftci, S., Neudorfer, B., Schmitz, S., Hess, H. (2012). Next Generation System-Wide Liquidity Stress Testing. IMF. Working Paper No. 3, https://doi. org/10.5089/9781475502466.001

van den End, J. W. (2008). Liquidity Stress-Tester: A Macro Model for Stress-Testing Banks' Liquidity Risk. Netherlands Central Bank (DNB). Working Paper No. 175.

van den End, J. W. (2012). Liquidity Stress-Tester: Do Basel III and Unconventional Monetary Policy Work? Applied Financial Economics, 22(15), 1233-1257, https://doi.org/10.1080/0960 3107.2011.646065

Vodová, P. (2011a). Liquidity of Czech commercial banks and its determinants. International Journal of Mathematical Models and Methods in Applied Sciences, 5(6), 1060-1067.

Vodová, P. (2011b). Determinants of Commercial Bank's Liquidity in Slovakia. In Lessons Learned from the Financial Crisis. Proceedings of 13th International Conference on Finance and Banking (pp. 740-747).

Vodová, P. (2012). Determinants of Commercial Banks' Liquidity in Poland. Ratio, 50(2).

Vodová, P. (2013). Liquid Assets in Banking: What Matters in the Visegrad Countries? E a M: Ekonomie a Management, 16, 113-129.

Vodová, P. (2013b). Determinants of Commercial Bank Liquidity in Hungary. e-Finanse: Financial Internet Quarterly, 9(3), 64-71.

Wong, E., Hui, C.-H. (2009). A Liquidity Risk Stress-Testing Framework with Interaction between Market and Credit Risks. Hong Kong Monetary Authority. Working Paper No. 6, https://doi.org/10.2139/ssrn.137 